\begin{tabular}{ll}
\hline Jurnal Sastra Indonesia \\
http://journal.unnes.ac.id/sju/index.php/jsi
\end{tabular}

\title{
Tatanan Sosial Masyarakat Jawa dalam Puisi Bolong Karya Joko Pinurbo
}

Turahmat $^{\bowtie}$

Program Studi Pendidikan Bahasa dan Sastra Indonesia, Fakultas Keguruan dan Ilmu Pendidikan, Universitas Islam Sultan Agung, Semarang, Indonesia

\section{Info Artikel}

Sejarah Artikel:

Diterima November 2018

Disetujui Mei 2019

Dipublikasikan Juli 2019

Kata kunci: masyarakat Jawa,

tatanan

sosial, puisi

Keywords:

Social Order;

Javanese

Society;

Poetry

\begin{abstract}
Abstrak
Masyarakat Jawa merupakan masyarakat yang berlapis dengan penandaan golongan melalui suatu cara hidup. Masyarakat Jawa memiliki tatanan sosial yang mengatur anggotanya untuk senantiasa dijadikan pedoman dan tidak diabaikan sehingga melekat dalam pribadi sebagai identitas. Tatanan nilai sosial dapat diungkapkan melalui berbagai hal, salah satunya melalui karya sastra. Penelitian ini bertujuan mengungkap tatanan sosial masyarakat Jawa dalam puisi Bolong karya Joko Pinurbo. Penelitian ini dilakukan menggunakan metode deskriptif kualitatif. Data dalam penelitian ini adalah tatanan nilai sosial yakni Urip ora ngoyo, nrimo ing pandom, Ngajeni wong tua, dan ana catur mungkur yang bersumber dari puisi Bolong.
\end{abstract}

\section{Abstract}

Javanese society is a society that is layered with the designation of groups through a way of life. Javanese society has a social order that regulates its members to always be used as a guideline and not neglected so that it is inherent in the person as identity. The order of social values can be expressed through various things, one of which is through literature. This study aims to reveal the social fabric of Javanese society in Bolong poetry by Joko Pinurbo. This research was conducted using qualitative descriptive methods. The data in this study are social value structures, namely Urip ora ngoyo, nrimo ing pandom, Ngajeni wong tua, and chess games which are derived from Bolong poetry.

(C) 2019 Universitas Negeri Semarang

\begin{tabular}{lr}
\hline Alamat korespondensi: & P-ISSN 2252-6315 \\
Kampus Unisula, Jln. Kaligawe Raya No.KM. 4, Terboyo Kulon, & E-ISSN 2685-9599 \\
Kota Semarang, Jawa Tengah 50112 & \\
E-mail: lintangsastra@unissula.ac.id &
\end{tabular}




\section{PENDAHULUAN}

Indonesia merupakan negara dengan masyarakat majemuk. Kemajemukan masyarakat yang dimiliki oleh bangsa Indonesia memberikan penekanan penting yang menjadi ciri khusus antar suku bangsa sebagai identitas masyarakat termasuk di Jawa. Kemajemukan itu sendiri dapat berupa tatanan nilai sosial yang terkandung dalam masyarakat. Tatanan nilai sosial merupakan susunan kehidupan untuk menata hidup menjadi seorang pribadi atau masyarakat sesuai dengan nilai-nilai atau kaidah masyarakat yang berlaku dimana seseorang tersebut berada. Masyarakat Jawa menjadi salah satu masyarakat yang memiliki adat istiadat serta nilai sosial kehidupan yang selalu mendarah daging dalam diri setiap individu masyarakat.

Masyarakat Jawa merupakan masyarakat yang berlapis. Maryarakat berlapis sendiri adalah masyarakat dengan penandaan golongan melalui suatu cara hidup. Sebuah masyarakat berlapis mempunyai tata krama yang bersifat kompleks karena masyrakat berlapis memiliki aturanaturan tertentu yang dapat mengatur anggota masyarakatnya. Sebab hal tersebut, masyarakat Jawa memiliki tatanan sosial yang mengatur anggotanya untuk senantiasa dijadikan pedoman dan tidak diabaikan sehingga melekat dalam pribadi sebagai identitas.

Tatanan nilai sosial dapat diungkapkan melalui berbagai hal yakni salah satunya melalui karya sastra. Karya sastra adalah sebuah karya cipta yang dihasilkan oleh penulis tentang maksudnya dengan cara mudah dipahami oleh pembaca yang bernilai keindahan. Karya sastra menceritakan tentang kisah hidup yang disebarkan melalui media sesuai zamannya. Selain itu, karya sastra pula merupakan ungkapan seseorang berupa pengalaman, pengetahuan, ide maupun keyakinan tentang ilustrasi kehidupan. Karya sastra adalah usaha untuk merekam isi jiwa dari sastrawannya menggunakan alat bahasa yang akan disampaikan kepada orang lain (Sumardjo, 1986).

Sebuah karya sastra dapat memberikan kepuasan batin dan kegemberiaan terhadap si penulis karena karya sastra dapat menjadi pengalaman untuk berkarya. Bukan hanya itu, karya sastra pula merupakan media untuk menuangkan hasil pikiran dan perasaan dalam tulisan bernilai keindahan dan pengajaran. Membaca sebuah karya sastra dapat memperluas pengetahuan seseorang mengenai budaya ataupun kehidupan sosial dari masyarakat tertentu yang diciptakan oleh pengarang. Terdapat bermacam aspek sosial yang dapat diangkat menjadi sebuah kisah cerita untuk disuguhkan dalam bentuk karya sastra. Telah banyak pandangan hidup dari masyarakat Jawa yang kemudian dijadikan karya sastra baik prosa ataupun puisi (Herusatoto, 2008:114).

Karya sastra dapat memberikan gambaran mengenai kehidupan dari suatu wilayah tertentu sehingga mampu menyampikan arti bagi para pembaca karya tersebut. Karya sastra dan masyarakat memiliki ikatan yang kuat. Karya sastra dapat mengutarakan kondisi sosial serta kebudayaan yang terkandung dalam masyarakat. Sistem nilai kebudayaan adalah tingkatan tertinggi dan bersifat sangat abstrak dalam adat istiadat. Hal tersebut terjadi karena nilai-nilai dari dalam sebuah budaya merupakan konsep tentang apa yang tumbuh di dalam pikiran masyarakat tertentu yang dapat berfungsi sebagai pedoman hidup (Koentjaraningrat, 2002:190). Karya sastra sendiri terdiri dari berbagai macam. Karya sastra terdiri dari drama, naratif yang meliputi novel, cerita pendek serta novelette, dan puisi (Wiyatmi, 2006:27). Puisi sendiri adalah bentuk karya sastra yang terikat oleh irama, rima serta penyusunan bait dan baris yang bahasanya terlihat indah dan penuh makna. Puisi termasuk karya sastra yang dijadikan penulis sebagai media komunikasi terhadap kondisi maupun fenomena tertentu melalui penggunaan diksi yang dipilih.

Pembahasan dalam penulisan ini mengenai tatanan nilai sosial masyarakat Jawa yang ditangkap dari puisi Bolong. Penelitian ini dilakukan untuk mengungkapkan tatanan nilai sosial terlebih pada masyarakat Jawa yang terdapat pada puisi Bolong karya dari Joko Pinurbo. Dipilihnya puisi tersebut karena dilatar belakangi oleh keberadaan nilai-nilai kehidupan budaya lokal yang belum dipahami oleh 
masyarakat luas dalam puisi tersebut. Pada zaman yang seperti ini, masyarakat Jawa memiliki nilai sosial yang telah menjadi sebuah kebudayaan namun masih banyak pula masyarakat yang mengabaikan bahkan tidak mengerti tentang hal tersebut. Menanggapi hal tersebut, masyarakat membutuhkan solusi serta orientasi yang tepat mengingat di Jawa memiliki tatanan nilai sosial yang bervariasi. Penyadaran masyarakat mengenai tatanan nilai sosial dapat memberikan hasil yang efektif karena puisi mampu berkembang di tengah-tengah masyarakat. Tatanan nilai sosial tersebut yakni urip ora ngoyo, nrimo ing pandom, ngajeni wong tua, ana catur mungkur.

Penelitian tentang potret kondisi sosial masyarakat jawa dalam karya sastra juga telah dilakukan oleh Bagus Wahyu Setyawan, dkk (2018)

\section{METODE}

Pada kegiatan penelitian ini dilakukan dengan menggunakan metode deskriptif kualitatif yakni suatu prosedur penelitian yang menggunakan data deskriptif berupa kata-kata tertulis maupun lisan. Metode deskriptif kualitatif merupakan penelusuran fakta melalui penafsiran yang tepat (Whitney, 1960). Data dalam penelitian ini adalah tatanan nilai sosial yakni Urip ora ngoyo, nrimo ing pandom, Ngajeni wong tua, Ana catur mungkur yang bersumber dari puisi "Bolong". Pengumpulan data dalam penelitian ini dilakukan dengan teknik baca catat yakni mengumpulkan data dengan cara membaca teks yang menjadi sumber penelitian dengan memberikan tanda pada karya tersebut.

Dalam pengumpulan data, langkah yang dilakukan yaitu (1) membaca puisi Bolong secara intensif, (2) mengidentifikasi dan mengelompokkan tatanan nilai kehidupan yakni urip ora ngoyo, nrimo ing pandom, ngajeni wong tua, ana catur mungkur yang terdapat dalam puisi Bolong, (3) mendeskripsikan tatanan nilai sosial yakni urip ora ngoyo, nrimo ing pandom, ngajeni wong tua, ana catur mungkur yang terdapat dalam puisi Bolong.
Pada proses analisis data metode yang digunakan adalah deskriptif analisis dan analis isi. Menurut Ratna (2004:48) metode deskriptif analisis merupakan metode yang dipergunakan dengan cara mendeskripsikan data berupa faktafakta yang didukung oleh analisis. Data-Data yan telah terkumpul dianalis kemudian disimpulkan tentang apa yang menjadi hasil analisis sesuai dengan apa yang menjadi pembahasan pada penelitian ini. Kegiatan ini dilakukan dengan cermat dan teliti sehingga mendapatkan hasil mengenai tatanan nilai kehidupan yang disampaikan oleh Joko Pinurbo dalam penulisan puisi Bolong. Sedangkan kegiatan analisis data, penulis mendeskripsikan makna yang tersimpan dalam gaya bahasa yang digunakan.

\section{HASIL DAN PEMBAHASAN}

\section{Tatanan Sosial Masyarakat Jawadalam Puisi Bolong}

Lingkungan hidup sosial yang menjadi tempat untuk kegiatan interaksi antar individu maupun kelompok akan senantiasa memiliki aturan berupa kumpulan norma maupun nilai yang menjadi tatanan sosial yang mengatur kehidupan dari anggota masyarakat. Tatanan sosial sering disebut sebagai tatanan masyarakat yang artinya adalah keseluruhan dari ikatan peraturan dan kelembagaan yang secara khusus mengatur struktur masyarakat, hubungan antar anggota masyarakat hingga hubungan antar kelompok masyarakat. Norma-Norma dalam tatanan masyarakat mengatur segala bentuk status masyarakat yang terikat di dalamnya. Setiap individu yang menjadi anggota masyarakat harus paham dengan baik mengenai aturan yang menjadi tatanan sosialnya.

Pada kehidupan masyarakat Jawa pun memiliki sikap hidup yang menjadi tatanan sosial untuk dapat menjaga keutuhan hidup antar masyarakat. Orang Jawa memiliki sikap hidup yang rila, sabar serta nrima dalam menjalani kehidupan (Jong dalam Endraswara dalam Ika Dwi, 2012:3). Sikap hidup seiring dengan berjalannya masa akan tumbuh menjadi kebudayaan jika ia dikelilingi oleh tatanan sosial yang selalu mengaturnya. Kebudayaan itulah 
yang kemudian muncul menjadi gambaran dari suatu daerah.

Masyarakat Jawa memiliki tatanan sosial yang mengatur anggota masyarakatnya dalam melakukan kehidupan. Tatanan sosial tersebut terbentuk akibat dari perilaku masyarakatnya yang terkadang tidak sesuai dari apa yang menjadi tatatan. Perilaku sendiri terjadi sebagai dampak dari rangsangan yang timbul dari dalam maupun luar (Sunaryo dalam Suparyanto, 2010). Untuk dapat menjadi anggota masyarakat Jawa, maka seseorang harus dapat menyesuaikan diri pada lingkugan yang dihuni. Menurut Mulder dalam jurnal dari Darmoko dengan judul Budaya Jawa dalam Diaspora pengakuan sosial yang menjadi dampak dari sikap individu merupakan sanksi untuk menghakimi orang-orang yang tidak patuh (1984: 64).

Siti Nurfajriah mengatakan pada jurnalnya berjudul Nilai Moral dalam Novel Orang Miskin Dilarang Sekolah (2014:25) bahwa budaya Jawa memiliki kemampuan dalam menerima kebudayaan luar namun mampu untuk mempertahankan kebudayaan miliknya. Namun seiring berjalannya waktu dan situasi, remaja pada masyarakat Jawa cenderung terkikis dengan globalisasi yang membawa arus kebudayaan asing menjadikan mereka lupa akan tatanan sosial yang harusnya dilestarikan serta dijunjung tinggi keberadaannya. Dalam puisi Bolong yang menjadi karya dari Joko Pinurbo mengandung nilai-nilai tatanan sosial Jawa yang dapat dijadikan renungan kita sebagai anggota dari masyarakat Jawa. Tatanan sosial yang dimaksudkan adalah:

\section{Urip ora ngoyo}

Tatanan sosial yang pertama adalah urip ora ngoyo yang berarti jangan berusaha terlalu keras atau kuat. Masyarakat Jawa lebih senang melakukan sesuatu kegiatan atau pekerjaan dengan santai tanpa menggebu-gebu. Selain itu masyarakat Jawa lebih nyaman melakukan sesuatu secara pelan-pelan namun membuahkan hasil yang baik karena suatu pekerjaan yang dilakukan dengan tergesa-gesa akan membuat kita menjadi kurang teliti sehingga hasil yang diperoleh terkadang tidak sesuai dengan apa yang menjadi harapan.

Tatanan sosial ini tidak berarti mengajarkan untuk mengerjakan pekerjaan dengan seenaknya tanpa perduli dengan peraturan yang berlaku. Urip ora ngoyo sendiri mengandung tujuan agar masyarakat Jawa memiliki cita-cita yang dapat tercapai tanpa adanya keinginan yang terlalu ambisius. Tatanan sosial ini mengajarkan bahwa apapun yang kita dapatkan dengan cara yang tidak baik akan memberikan dampak yang merugikan. Dalam puisi Bolong terdapat bait yang menggambarkan tatanan sosial urip ora ngoyo yakni:

Bahkan celana memilih jalannya sendiri:

Ia pergi ke pasar loak justru ketika aku sedang giat belajar

Pada bait tersebut dijelaskan bahwa sesuatu yang digambarkan melalui kata celana melakukan apa yang menjadi pilihan dan harapannya. Si celana mengajarkan untuk tidak terlalu berambisi dalam mencapai keinginannya. Ia memilih untuk melakukan pekerjaannya tanpa berusaha terlalu ambisius dan giat seperti yang dilakukan oleh tokoh Aku. Ia memiliki cara tersendiri untuk menyelesaikan pekerjaan dengan hati-hati.

\section{Nrimo ing pandom}

Nrimo ing pandom berarti menerima apapun yang menjadi rejeki dengan hati yang luas. Dalam artian yang lebih luas, nrimo ing pandom adalah ikhlas atas apa yang kita dapatkan. Nrimo ing pandom mendidik masyarakat Jawa untuk menerima segala sesuatu baik dari manusia maupun tuhan dengan kebaikan hati. Seseorang cenderung memiliki keinginan untuk mendapatkan sesuatu sebagai imbalan ketika melakukan suatu hal. Namun manusia terkadang lupa bahwa kita juga harus memberikan sesuatu yang baik ketika kita memiliki harapan mendapatkan sesuatu. Dalam puisi Bolong terdapat bait yang menggambarkan tatanan sosial nrimo ing pandom yakni: 


\author{
Ia pergi ke pasar loak justru ketika aku sedang \\ giat belajar bugil dan mandi \\ Selamat tinggal pantat....
}

Pada bait tersebut tokoh $\mathrm{Aku}$ ditinggal oleh si celana. Tokoh aku mencoba untuk menerima kenyataan bahwa ia harus ditinggalkan oleh rekannya. Bait di atas menggambarkan bahwa Aku ikhlas menerima apa yang menjadi pemberian dari Tuhan bahwa ia harus berjuang sendiri tanpa bantuan dan dukungan dari orang lain. Selain itu pula, dalam bait di atas tokoh $\mathrm{Aku}$ ingin memberikan pengajaran bahwa kita harus senantiasa menerima apapun yang menjadi takdir kita dengan ketabahan hati walaupun apa yang diberikan pada kita terasa berat untuk dilalui.

\section{Ngajeni wong tua}

Dalam kehidupan di wilayah Jawa, masyarakat harus memiliki tata krama yang lebih sering disebut sebagai unggah-ungguh. Tata krama sendiri merupakan suatu aturan bersifat baik yang berisi sopan santun. Tata krama merupakan sesuatu yang tidak dapat terlepas dari kegiatan sehari-hari masyarakat Jawa karena tata krama menjadi tatanan sosial pada lingkungan Jawa.

Salah satu tata krama yang menjadi tatanan sosial masyarakat Jawa adalah "ngajeni wong tua". Ngajeni wong tua mengandung artian bahwa kita sebagai manusia harus menghormati siapa pun orang yang lebih tua dari diri kita. Tatanan sosial ini dilakukan kapan pun dan dimana pun seseorang itu berada. Masyarakat membiasakan tatanan sosial ini karena keberadaan seseorang yang lebih tua sangatlah penting. Orang Jawa memiliki sikap khas yaitu sopan dan hormat (Suseno, 1996). Dalam puisi Bolong terdapat penggambaran tatanan sosial ngajeni wong tua pada bait berikut ini.

"Pulang dan pakailah celana kesayanganmu ini"

Kata perempuan tua penjaga makam

Sampai di rumah, ku pakai kembali si celana hilang itu
Seperti penjelasan sebelumnya, pada bait di atas memberikan gambaran bahwa tokoh $\mathrm{Aku}$ dengan senang hati menerima celana yang diberikan oleh perempuan tua penjaga makam. Tokoh Aku menghormati perempuan tua itu dengan menjalankan apa yang telah diperintahkan kepadanya. Adanya hal tersebut menunjukkan bahwa penulis ingin mengingatkan dan mengajarkan kepada pembaca terlebih pada masyarakat Jawa melalui tokoh Aku untuk senantiasa menghormati orang yang lebih tua. Dalam puisi Bolong terdapat pesan untuk pembaca yakni kita harus melestarikan tatanan sosial ngajeni wong tua seperti yang dilakukan oleh tokoh Aku.

\section{Ana catur mungkur}

Ana catur mungkur adalah tatanan sosial yang memiliki makna untuk menggambarkan tentang keburukan atau kelemahan dari orang lain. Mudahnya ana catur mungkur adalah tidak menghiraukan perkataan yang dilontarkan seseorang kepada kita yang bersifat jelek atau menjatuhkan. Tatanan sosial ini mengatur masyarakat Jawa bahwa kita tidak boleh menggunjing seseorang karena hal tersebut dapat mengakibatkan perselisihan antar sesama. Kebanyakan pada masa sekarang orang-orang akan saling menjatuhkan untuk mencapai apa yang diinginkan.

Tatanan sosial ana catur mungkur ada untuk mengatur masyarakat Jawa untuk tidak membicarakan kejelekan dari orang lain. Selain hal itu kita diajarkan untuk tidak peduli dengan apa yang dibicarakan oleh orang lain terlebih tentang perkataan yang bersifat menjatuhkan. Dalam puisi Bolong bait yang menggambarkan ana catur mungkur yakni:

Bahkan celana memilih jalannya sendiri :

Ia pergi ke pasar loak justru ketika aku sedang giat belajar

Pada bait tersebut penulis menggambarkan bahwa seolah-olah si celana meninggalkan tokoh Aku ketika ia sedang berusaha dengan keras dalam belajar. Namun di sisi lain, gambaran yang muncul adalah tatanan sosial ana catur mungkur. 
Hal itu dapat terlihat dengan si celana tidak mendengarkan apa yang dikatakan oleh tokoh Aku. Dibandingkan memikirkan apa yang dikatakan oleh tokoh Aku, si celana lebih memilih fokus pada jalan yang dipilihnya untuk mencapai harapannya. Pada bait ini, pesan yang ingin disampaikan adalah kita sebagai manusia harus dapat memilah apa yang baik bagi diri kita dan tidak perlu mendengarkan perkataan yang tidak penting bagi kita.

\section{SIMPULAN}

Masyarakat Jawa merupakan masyarakat yang berlapis dengan penandaan golongan melalui suatu cara hidup. Sebab hal tersebut, masyarakat Jawa memiliki tatanan sosial yang mengatur anggotanya untuk senantiasa dijadikan pedoman dan tidak diabaikan sehingga melekat dalam pribadi sebagai identitas. Tatanan nilai sosial pada puisi Bolong ini diungkapkan melalui empat hal yaitu: urip ora ngoyo, nrimo ing pandom, ngajeni wong tua, dan ana catur mungkur.

\section{DAFTAR PUSTAKA}

Darmoko Tt. "Budaya Jawa Dalam Diaspora: Tinjauan Pada Masyarakat Jawa Di Suriname". Diunduh dari https://www.google.com/url?sa=t\&source=web\&r ct=j\&url=https://journal.uny.ac.id/index.php/ikad budi/article/download/12307/8764\&ved=2ahUKE wiIxLbT8uTfAhVEtY8KHdP0BoAQFjAAegQIAR AB\&usg=AOvVaw1tg6mFiOlTRI4eg9Jtup2c

Endraswara. (2006). Budi Pekerti Jawa. Yogyakarta: Buana Pustaka

Herusatoto, B. (2008). Simbiolisme Jawa. Yogyakarta: Ombak.

Ika Dwi Astutik. (2012). "Budaya Jawa Dalam Novel Tirai Menurun Karya N.H Dini'. Diunduh dari laman

https://www.google.com/url?sa=t\&source=web\&r $\mathrm{ct}=\mathrm{j} \& u r l=\mathrm{http}: / /$ jurnalmahasiswa.unesa.ac.id/inde x.php/jurnal-

sapala/article/view/1993\&ved=2ahUKEwiA 6u9OTfAhWGvo8KHQwFC54QFjAAegQIAxAB \&usg=AOvVaw1xX9R 0dcXCoZZXztrq6bG

Koentjaraningrat. (1979). Pengantar Ilmu Antropologi. Jakarta: Aksara Baru.

Ratna. (2004). Teori, Metode, Teknik Penelitian Sastra. Yogyakarta: Pustaka Pelajar.

Ratna. (2013). Paradigma Sosiologi Sastra. Yogyakarta: Pustaka Pelajar.

Sumardjo, J. (1986). Apresiasi Kesusastraan. Jakarta: Gramedia.
Suparyanto. (2010). "Artikel Tentang Kepatuhan". Diunduh dari laman http://drsuparyanto.blogspot.com/2010/07/k onsep-kepatuhan.html.

Siti Nurfajriah. (2014). "Nilai Moral Dalam Novel Orang Miskin Dilarang Sekolah Karya Wiwid Prasetyo Dan Implikasinya Terhadap Pembelajaran Bahasa Dan Sastra Di Sekolah". Diunduh dari laman https://www.google.com/url?sa=t\&source=web\&r $\mathrm{ct}=\mathrm{j} \& u r l=\mathrm{http}: / /$ repository.uinjkt.ac.id/dspace/bits tream/123456789/24432/1/Siti\%2520Nurfajriah\%2 $520-$

\%2520\%2528109013000007\%2529Watermark.pdf\& ved=2ahUKEwitwrrq8-

TfAhVJPo8KHVTFB1AQFjAAegQIBhAC\&usg=A OvVaw28wbEWOc7LUCCntp8-sQb7

Wahyu, Bagus. (2018). Potret Kondisi Sosial Masyarakat Jawa dalam Naskah Ketoprak Klasik Gaya Surakarta. Jurnal Aksara.

Whorf, B.L. (1956). Language, Thought, and Reality. Massachusetts: The M.I.T. Press. 